\title{
Characteristics Ruthenium (N719) as a Photosensitizer in Dye-Sensitized Solar Cells (DSSC)
}

\author{
Hardani $^{1}$, Cari $^{2}$, Agus Supriyanto ${ }^{3}$ \\ ${ }^{1}$ Program Studi DIII Farmasi, Politeknik Medica Farma Husada Mataram Jl. Medica Farma No.1 \\ Lingkungan Batu Ringgit Selatan, Sekarbela, Mataram \\ 2,3 Program Studi S3 Ilmu Fisika, Pascasarjana Universitas Sebelas Maret, Jl. Ir. Sutami no 36 \\ Kentingan Surakarta
}

Email: danylastchild07@gmail.com

\begin{abstract}
The study aims to characterize Ruthenium as a photosensitizer in Dye-Sensitized Solar Cells (DSSC). Samples are made in the structure of the working electrode pair Sandwich and the opponent electrode. Sample absorbancy test using UV-Visible LAMBDA 25 spectrophotometer and test current and voltage characterization (I-V) using Keithley 2602A. The $\mathrm{TiO}_{2}$ deposition method uses the drop and soaks method. The results of the study showed that the maximum absorbancy in the high dye ruthenium appeared at the two peaks at $=448 \mathrm{~nm}$ and $=580 \mathrm{~nm}$. While I-V curve measurements showed great efficiency that resulted in ruthenium dye with concentrations of $0.1,0.5$, and 1 in a row were $0,12 \%$, $0.186 \%$, and $0.26 \%$. These results show that higher concentrations of ruthenium dye can increase the value of the resulting efficiency.
\end{abstract}

Keywords: Dye-Sensitized Solar Cells (DSSC). Ruthenium, Sensitizer, $\mathrm{TiO}_{2}$, Efficiency

\begin{abstract}
Abstrak: Penelitian ini bertujuan untuk mengkarakterisasi Ruthenium sebagai fotosensitizer pada DyeSensitized Solar Cells (DSSC). Sampel dibuat dalam struktur kerja pasangan elektroda Sandwich dan elektroda lawan. Uji absorbansi sampel menggunakan spektrofotometer UV-Visible LAMBDA 25 dan uji karakterisasi arus dan tegangan (I-V) menggunakan Keithley 2602A. Metode pengendapan TiO2 menggunakan metode drop and soaks. Hasil penelitian menunjukkan bahwa absorbansi maksimum pada zat warna rutenium tinggi muncul pada dua puncak yaitu $=448 \mathrm{~nm}$ dan $=580 \mathrm{~nm}$. Sedangkan pengukuran kurva I-V menunjukkan efisiensi yang sangat baik yang menghasilkan pewarna rutenium dengan konsentrasi $0,1,0,5$, dan 1 berturut-turut adalah $0,12 \%, 0,186 \%$, dan $0,26 \%$. Hasil tersebut menunjukkan bahwa semakin tinggi konsentrasi zat warna rutenium dapat meningkatkan nilai efisiensi yang dihasilkan.
\end{abstract}

Kata kunci: Dye-Sensitized Solar Cells (DSSC). Ruthenium, Sensitizer, TiO2, Efisiensi

\section{PENDAhUluan}

Sel surya berdasarkan perkembangan teknologi saat ini dan bahan manufaktur dapat dibedakan menjadi tiga (Chang, Chen, Kao, Chien, \& Chou, 2013). Pertama, sel surya yang terbuat dari silikon tunggal, dan silikon multi-kristal. Kedua, sel surya lapisan tipis dan sel surya organik ketiga (Dye-Sensitized Solar Cell)(Joshi, Korfiatis, Potamianou, \& Thoma, 2013). Sel surya konvensional dalam bentuk koneksi persimpangan P-n yang terbuat dari bahan semikonduktor seperti silikon, masih mahal untuk dikembangkan karena penggunaan teknologi canggih (Cho, Lee, Lee, Jun, \& Park, 2010). Sampai ditemukan oleh Gratzel yaitu sel surya organik, DSSC sebagai sel surya dengan pewarna sensitizer dari bahan organik dapat dikembangkan dengan biaya yang murah dan pembuatan yang mudah (Ho Soon Min, Hardani, Cari, 2020).

DSSC berbeda dari sel surya komersial berbasis silikon, di mana sel surya DSSC terjadi antara pemisahan fungsi penyerapan cahaya dan pembawa transportasi elektronnya (Bayod- 
Rújula, 2019). Keuntungan DSSC dibandingkan dengan sel surya komersial yaitu murah, pembuatannya mudah, dan memiliki efisiensi tinggi bahkan pada intensitas cahaya kurang (Hardani, Cari, \& Supriyanto, 2018). DSSC adalah sel surya photoelectrochemical sehingga digunakan elektrolit sebagai media muatan transportasi. DSSC dibagi menjadi beberapa bagian yang terdiri dari $\mathrm{TiO}_{2}$ nano partikel, molekul pewarna adsorpsi pada permukaan $\mathrm{TiO}_{2}$, dan katalis yang semuanya disimpan di antara dua kaca konduktif (Sharma, Sharma, \& Sharma, 2018). Struktur DSSC terlihat seperti gambar 1.

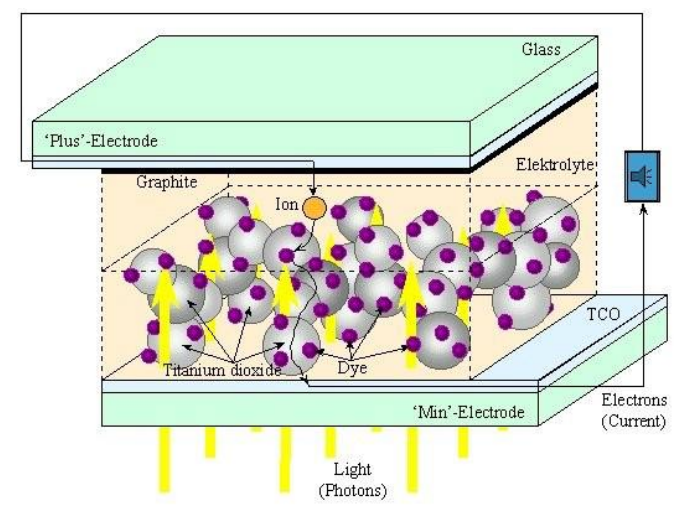

Gambar 1. Struktur Dye-Sensitized Solar Cells (DSSC) (Hardani, Darmaja, Darmawan, Cari, \& Supriyanto, 2016)

Prinsip kerja DSSC yaitu mengubah energi cahaya menjadi listrik dalam skala molekuler dalam bentuk reaksi dari transfer electron (Sharma et al., 2018). Proses pertama dimulai dengan eksitasi elektron dalam pewarna karena penyerapan foton. Ini adalah salah satu peran sifat $\mathrm{TiO}_{2}$. Ketika foton sinar matahari/lampu halogen menimpa elektroda kerja di DSSC, energi foton diserap oleh pewarna yang melekat pada permukaan $\mathrm{TiO}_{2}$. Jadi pewarna mendapat energi untuk dicatat. Pewarna dicatat sebagai membawa energi dan disuntikkan ke dalam pita konduksi di $\mathrm{TiO}_{2} . \mathrm{TiO}_{2}$ berfungsi sebagai penerima elektron. Molekul pewarna yang ditinggalkan kemudian dalam keadaan teroksidasi. Selanjutnya, elektron akan ditransfer melalui sirkuit luar ke elektroda. Elektrolit (pasangan iodida dan triiodide) Bertindak sebagai mediator elektron sehingga mereka dapat menghasilkan proses siklus dalam sel. Triode Ion menangkap elektron yang berasal dari kisaran luar dengan bantuan molekul karbon katalis. Elektron masuk kembali ke dalam sel dan dibantu oleh karbon sehingga dapat bereaksi dengan elektrolit yang menyebabkan penambahan ion iodida ke elektron. Kemudian ion iodida dalam elektrolit memberikan energi pembawa elektron ke pewarna teroksidasi. Elektrolit menyediakan elektron pengganti untuk molekul pewarna teroksidasi (Khatibi, Razi Astaraei, \& Ahmadi, 2019).

Penelitian ini menggunakan ruthenium sebagai pewarna. Ruthenium adalah salah satu unsur kimia dengan nomor atom 44. Elemen ini berada di grup 8 dengan lambang Ru. Ruthenium adalah logam transisi warna keperihan, keras, dan memiliki titik leleh atau titik didih tinggi (Khatibi et al., 2019). Senyawa yang paling umum untuk elemen ini adalah ruthenium trichloride. Senyawa ini berbentuk padatan merah dan banyak digunakan sebagai bahan kimia sintetis (Cari, Supriyanto, Fadli, \& Prasada, 2016). Penggunaan senyawa ini dikenal dalam bentuk ruthenium dioksida dikombinasikan dengan timbal dan bismuth ruthenate sebagai resistor film tipis (Kitai, 2011). Sehingga ruthenium adalah katalis yang baik untuk meningkatkan efisiensi sel surya (Chae, Kim, Kim, \& Kang, 2010). Penelitian ini bertujuan untuk mengidentifikasi dan menkarakteristik Ruthenium sebagai photosensitizer dalam DyeSensitized Solar Cells (DSSC). Gambar 2. Ini adalah kurva I-V sel yang menghasilkan tegangan dan arus. Gambar 2 menyajikan tegangan sirkuit terbuka ( $\mathrm{V}_{\mathrm{OC}}$ ), arus arus pendek (Iis), tegangan 
maksimum, arus maksimum dan faktor pengisian. Ketika kondisi korsleting (Iis), sel akan menghasilkan arus arus pendek. Ketika kondisi sirkuit terbuka tidak ada arus yang mengalir sehingga ketegangan akan maksimum atau disebut dengan tegangan sirkuit terbuka. Faktor pengisian adalah ukuran kualitas kinerja sel surya (Wang, Wang, \& Li, 2011).

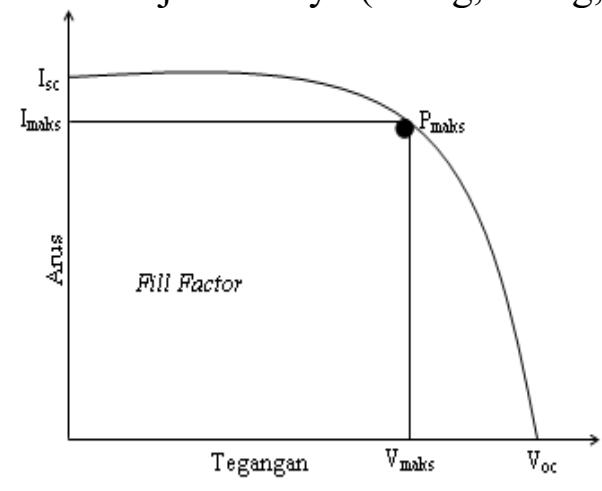

Gambar 2. Kurva I-V DSSC

Fill Factor (FF) adalah ukuran kuantitatif dari kualitas sel surya, serta ukuran persegi luar kurva I-V, Fill Factor dapat diperoleh menggunakan persamaan 1.

$$
F F=\frac{V_{m a k s} I_{m a k s}}{V_{o c} I_{s c}}
$$

Daya maksimum yang dihasilkan sel surya dapat diperoleh melalui persamaan 2 .

$$
P_{m a k s}=V_{o c} I_{s c} F F
$$

Efisiensi yang dihasilkan dari sel surya dapat diperoleh melalui persamaan 3.

$$
\eta=\frac{P_{m a k s}}{P_{i n}}
$$

Efisiensi menjadi ukuran kualitas sel surya. Efisiensi sel surya yang merupakan perbandingan kuantitatif dari daya maksimum yang dihasilkan sel (Pmax) dengan daya yang masuk sel $\left(\mathrm{P}_{\text {in }}\right)$ dapat ditentukan oleh persamaan (3).

\section{METODE PENELITIAN}

$\mathrm{TiO}_{2}$ yang digunakan dalam penelitian ini adalah nanopartikel Titanium (IV) dengan ukuran $21 \mathrm{~nm}$. $\mathrm{TiO}_{2}$ sebanyak 0,5 gr dilarutkan dalam $2 \mathrm{ml}$ etanol absolut yang diaduk selama 30 menit menggunakan pusaran styrer. $\mathrm{TiO}_{2}$ ditumpangkan pada kaca konduktif Fluorin Tin Oxide (FTO) dengan luasan $2 \mathrm{~cm}$ x 1,5cm untuk menggunakan metode spin coating. Lapisan deposisi $\mathrm{TiO}_{2}$ dipanaskan pada suhu $500^{\circ} \mathrm{C}$ selama 60 menit di atas hotplate. Penelitian ini menggunakan pewarna ruthenium yang dilarutkan menggunakan Iopropanol di mana penelitian sebelumnya menggunakan pelarut etanol (Hardani et al., 2016). Setelah diaduk dan didiamkan selama 24 jam pada suhu kamar. Konstruksi DSSC yang digunakan adalah sistem sandwich. Elektroda kerja dalam bentuk kaca konduktif FTO yang telah dilapisi dengan $\mathrm{TiO}_{2}$ yang telah direndam dengan pewarna ruthenium. Pada penelitian ini juga menggunakan variasi pendeposisian pelarut ruthenium dengan menggunakan teknik perendaman dan teknik tetes. 
Elektroda lawan adalah kaca konduktif FTO yang telah dilapisi dengan lapisan platina (Pt) (Hexachloroplatinic (IV) 10\%). Elektrolit terbuat dari $\mathrm{I}_{2} / \mathrm{KI}$ yang dilarutkan dalam PEG yang kemudian ditransmisikan antara elektroda lawan dan elektroda kerja diberi pelindung keyboard penghalang sehingga tidak terjadi korsleting. Elektroda yang bekerja dan elektroda lawan yang telah ditransmisikan oleh elektrolit kemudian ditumpuk dan disematkan menggunakan Clipboard. DSSC Sandwich kemudian diuji karakteristiknya.

\section{HASIL DAN PEMBAHASAN}

Penelitian ini menggunakan pewarna ruthenium yang dilarutkan dalam isopropanol sedangkan penelitian sebelumnya menggunakan pelarut etanol (Hardani et al., 2016). Kemudian di uji daya penyerapannya menggunakan Spectrophotometer UV Visible Shimadzhu 1601 PC dan pengukuran tegangan menggunakan I-V meter/ Elkahfi 100 dari I-V meter untuk menentukan nilai elektrolit dan konduktivitas pewarna. Penyerapan ruthenium diukur menggunakan Spektroskopi UV-Vis pada rentang panjang gelombang 350-800 nm. Gambar 3 menunjukkan penyerapan grafik Ruthenium dengan berbagai konsentrasi $0.1 \%, 0.5 \%$, dan $1 \%$.

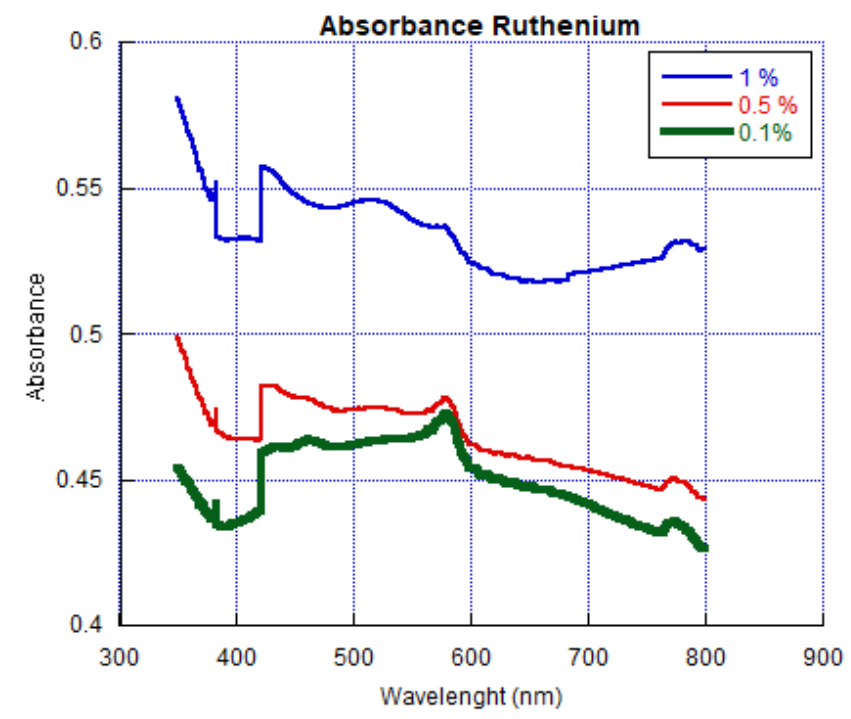

Gambar 3. Grafik absorbansi

Penyerapan ruthenium dalam penelitian ini memiliki puncak penyerapan pada kisaran panjang gelombang 300-600 nm (Gambar 3). Hasil yang sama diperoleh pada penelitian M. Gratzel (2003) (Grätzel, 2003), A. Khatibi et al 2015 (Khatibi et al., 2019), dan Yoneda et al. 2013 (Yoneda, Nazeeruddin, \& Craetzel, 2012), sehingga Ruthenium dapat menyerap cahaya pada rentang panjang gelombang cahaya tampak (visible). Arus Tegangan (I-V) adalah metode untuk mengetahui kinerja Dye-Sensitized Solar Cells yang merupakan seberapa banyak kemampuan DSSC dapat mengubah cahaya menjadi energi listrik dan pengukuran I-V dilakukan dalam kondisi gelap dan terang yaitu di bawah iluminasi lampu halogen dengan intensitas $1991 \mathrm{~W} / \mathrm{m}^{2}$. Nilai konduktivitas DSSC dapat dilihat pada Gambar 4. 


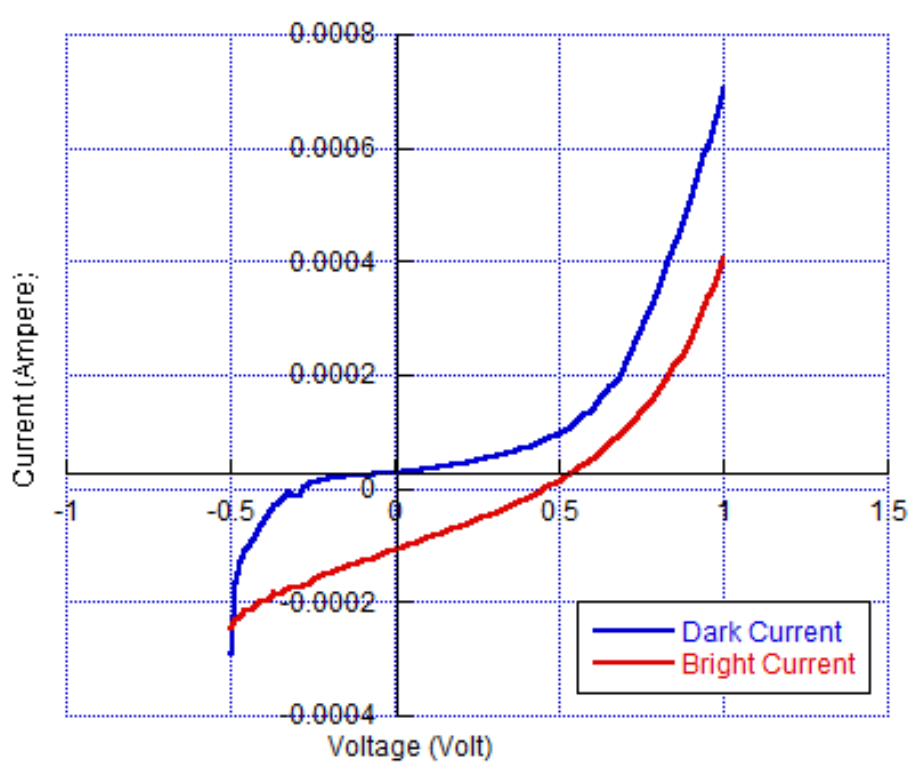

Gambar 4. Grafik Konduktivitas

Berdasarkan hasil karakterisasi Ruthenium "I-V Dye", memperoleh kurva I-V dalam kondisi gelap dan terang (Gambar 4). Nilai pewarna Ruthenium saat ini meningkat secara linear ketika nilai tegangan meningkat. Ketika jumlah konsentrasi pewarna Ruthenium meningkat, lebih banyak molekul pewarna Ruthenium akan menghasilkan elektron bebas (Chen et al., 2012). Ini adalah elektron bebas yang akan menghasilkan aliran muatan, sehingga akan menghasilkan arus (Valente, Garcia Poortmans \& Arkhipov, 2014). Karakteristik ini muncul dalam kondisi gelap dan terang. Gambar 4 menunjukkan bahwa pewarna ruthenium dapat menghasilkan arus listrik yang baik (Valente, Garcia Poortmans \& Arkhipov, 2014). Pengujian Kinerja DSSC variasi konsentrasi pewarna Ruthenium dilakukan untuk melihat efek konsentrasi pada kinerja yang dihasilkan oleh DSSC. Uji ini dilakukan dengan syarat menggunakan platinum sebagai elektroda lawan. Efisiensi yang dihasilkan oleh DSSC menggunakan Ruthenium dengan perlakuan pada $\mathrm{TiO}_{2}$ disajikan dalam tabel 1 .

Tabel 1. Efisiensi DSSC

\begin{tabular}{lllcccl}
\hline $\begin{array}{c}\text { Konsentrasi } \\
(\boldsymbol{\%})\end{array}$ & $\begin{array}{c}\text { Imax } \\
\text { (Ampere) }\end{array}$ & $\begin{array}{c}\text { Vmax } \\
(\text { Volt })\end{array}$ & $\begin{array}{c}\text { Isc } \\
\text { (Ampere) }\end{array}$ & $\begin{array}{c}\text { Voc } \\
(\text { Volt })\end{array}$ & $\begin{array}{c}\text { Fill } \\
\text { Factor }\end{array}$ & $\begin{array}{c}\text { Efisiensi } \\
(\boldsymbol{\%})\end{array}$ \\
\hline $\mathbf{0 . 1}$ & $0.7 \times 10^{-3}$ & 0.18 & $7.8 \times 10^{-3}$ & 0.33 & $1.2 \times 10^{-8}$ & 0.12 \\
$\mathbf{0 . 5}$ & $1.1 \times 10^{-3}$ & 0.23 & $2.1 \times 10^{-3}$ & 0.40 & $1.8 \times 10^{-8}$ & 0.186 \\
$\mathbf{1}$ & $4.6 \times 10^{-4}$ & 0.29 & $9 \times 10^{-4}$ & 0.58 & $2.1 \times 10^{-7}$ & 0.26 \\
\hline
\end{tabular}

Tabel 1 menyajikan efisiensi setiap DSSC dengan variasi konsentrasi yang berbeda pada saat intensitas pencahayaan yang sama $1991 \mathrm{~W} / \mathrm{m}^{2}$. Dari tabel 1 dapat dilihat bahwa DSSC yang menghasilkan kinerja terbaik adalah DSSC yang menggunakan pewarna Ruthenium dengan konsentrasi $1 \%$ dan menghasilkan efisiensi 0,26\%. Hal ini menunjukkan bahwa meningkatkan konsentrasi pewarna dapat mempengaruhi efisiensi DSSC.

\section{KESIMPULAN}

Pengukuran dan analisis penyerapan pewarna Ruthenium telah dilakukan dengan berbagai konsentrasi. Hasil penelitian menunjukkan bahwa pewarna Ruthenium memiliki spektrum penyerapan dalam panjang gelombang antara $300-600 \mathrm{~nm}$, sehingga Ruthenium mampu menyerap cahaya pada rentang panjang gelombang cahaya tampak (visible). Semakin tinggi 
konsentrasi maka semakin tinggi efisiensi yang dihasilkan. Hal ini membuat bahan ruthenium perlu diselidiki lebih lanjut sebagai bahan sensitizer DSSC. Peningkatan konsentrasi pewarna ruthenium dapat mempengaruhi kinerja DSSC.

\section{DAFTAR PUSTAKA}

Bayod-Rújula, A. A. (2019). Solar photovoltaics (PV). Solar Hydrogen Production: Processes, Systems and Technologies, 1(4), 237-295. https://doi.org/10.1016/B978-0-12814853-2.00008-4

Cari, Supriyanto, A., Fadli, U. M., \& Prasada, A. B. (2016). Fabrication and Characterization of Sansevieria trifasciata, Pandanus amaryllifolius and Cassia angustifolia as Photosensitizer for Dye Sensitized Solar Cells. Journal of Physics: Conference Series, 710(1). https://doi.org/10.1088/1742-6596/710/1/012027

Chae, J., Kim, D. Y., Kim, S., \& Kang, M. (2010). Photovoltaic efficiency on dye-sensitized solar cells (DSSC) assembled using Ga-incorporated TiO2 materials. Journal of Industrial and Engineering Chemistry, 16(6), 906-911. https://doi.org/10.1016/j.jiec.2010.09.012

Chang, H., Chen, C. H., Kao, M. J., Chien, S. H., \& Chou, C. Y. (2013). Photoelectrode thin film of dye-sensitized solar cell fabricated by anodizing method and spin coating and electrochemical impedance properties of DSSC. Applied Surface Science, 275, 252257. https://doi.org/10.1016/j.apsusc.2012.12.132

Chen, J., Bai, F. Q., Wang, J., Hao, L., Xie, Z. F., Pan, Q. J., \& Zhang, H. X. (2012). Theoretical studies on spectroscopic properties of ruthenium sensitizers absorbed to TiO 2 film surface with connection mode for DSSC. Dyes and Pigments, 94(3), 459-468. https://doi.org/10.1016/j.dyepig.2012.01.018

Cho, K. Y., Lee, S., Lee, Y.-G., Jun, Y., \& Park, J.-K. (2010). Enhancement of Dye-sensitized solar cell (DSSC) performance using polymeric spectacular reflectance film. PMSE Prepr., (Copyright (C) 2011 American Chemical Society (ACS). All Rights Reserved.), No pp. given. Retrieved from http://pubs.acs.org/cgi$\mathrm{bin} /$ preprints $/$ display?div $=$ pmse\&meet $=239 \&$ page $=5652 \_14320$. pdf

Grätzel, M. (2003). Dye-sensitized solar cells. Journal of Photochemistry and Photobiology C: Photochemistry Reviews, Vol. 4, pp. 145-153. https://doi.org/10.1016/S13895567(03)00026-1

Hardani, Cari, \& Supriyanto, A. (2018). Efficiency of dye-sensitized solar cell (DSSC) improvement as a light party TiO2-nano particle with extract pigment mangosteen peel (Garcinia mangostana). 020002. https://doi.org/10.1063/1.5054406

Hardani, H., Darmaja, H., Darmawan, M. I., Cari, C., \& Supriyanto, A. (2016). Pengaruh Perubahan Intensitas Cahaya Halogen Ruthenium (N719) Fotosensitizer Dalam DyeSensitized Solar Cell(Dssc). Jurnal Penelitian Fisika Dan Aplikasinya (JPFA), 6(2), 70. https://doi.org/10.26740/jpfa.v6n2.p70-76

Ho Soon Min, Hardani, Cari, A. S. (2020). Thin Film-Based Solar Cell and Dye-Sensitized Solar Cells: Review. 29(11), 2413-2426. Retrieved from http://sersc.org/journals/index.php/IJAST/article/view/22658/11539

Joshi, P. H., Korfiatis, D. P., Potamianou, S. F., \& Thoma, K.-A. T. (2013). Selected parameters leading to an optimized DSSC performance. Russian Journal of Electrochemistry, 
49(7), 628-632. https://doi.org/10.1134/S1023193513070045

Khatibi, A., Razi Astaraei, F., \& Ahmadi, M. H. (2019). Generation and combination of the solar cells: A current model review. Energy Science and Engineering, 7(2), 305-322. https://doi.org/10.1002/ese3.292

Kitai, A. (2011). Principles of Solar Cells, LEDs and Diodes e role of the PN junction. Retrieved from https://www.academia.edu/34222042/Principles_of_Solar_Cells_LEDs_and_Diodes e role_of the PN_junction_KITAI_KITAI_Principles_of_Solar_Cells_LEDs_and -Diodes_e_role_of_the_PN_junction

Sharma, K., Sharma, V., \& Sharma, S. S. (2018). Dye-Sensitized Solar Cells: Fundamentals and Current Status. Nanoscale Research Letters, 13. https://doi.org/10.1186/s11671018-2760-6

Valente, Garcia Poortmans, J., \& Arkhipov, V. (2014). Thin Film Solar Cells Fabrication, Characterization and Applications.

Wang, M., Wang, Y., \& Li, J. (2011). ZnO nanowire arrays coating on TiO2 nanoparticles as a composite photoanode for a high efficiency DSSC. Chemical Communications (Cambridge, England), 47(40), 11246-11248. https://doi.org/10.1039/c1cc15310b

Yoneda, E., Nazeeruddin, M. K., \& Craetzel, M. (2012). Cyclometalated Ruthenium Dyes for DSSC. Journal of Photopolymer Science and Technology, 25(2), 175-181. https://doi.org/10.2494/photopolymer.25.175 